\title{
Fruit and vegetable consumption in Scotland: analysis from the Expenditure and Food Survey
}

\author{
K. L. Barton ${ }^{1}$, A. Gregor ${ }^{2}$, W. L. Wrieden ${ }^{2}$, J. Armstrong ${ }^{3}$ and A. Sherriff ${ }^{4}$ \\ ${ }^{1}$ Centre for Public Health Nutrition Research, University of Dundee, Dundee DD1 9SY, UK, ${ }^{2}$ School of Pharmacy and \\ Life Sciences, Robert Gordon University, Aberdeen, AB25 1HG, UK, ${ }^{3}$ School of Life Sciences, Glasgow Caledonian \\ University, Glasgow G4 OBA, UK and ${ }^{4}$ Dental Public Health, Glasgow Dental School, Faculty of Medicine, \\ University of Glasgow, Glasgow G2 3JZ, UK
}

It is widely known that high intakes of fruit and vegetables are associated with lower rates of disease, and population targets of greater than $400 \mathrm{~g} / \mathrm{d}$ or "5 a day" are common in UK public health policy.

Household food purchase data from the UK Expenditure and Food Survey were analysed to estimate fruit and vegetable consumption in Scotland over the period 2001 to 2006 and by the Scottish Index of Multiple Deprivation (SIMD) for the period 2004 to 2006 . Adjustments were made for waste (values derived from the Department for Environment, Food and Rural Affairs ${ }^{(1)}$ and the Waste and Resource Action Programme survey of $2007^{(2)}$ ), and for the fruit and vegetable content of prepared dishes. Data were analysed using general linear models within the complex samples module of SPSS (SPSS Inc., Chicago, IL, USA) weighting to the Scottish population and taking account of sampling methods. The results are presented as population means (i.e. includes consumers and non-consumers) for household and eating out foods combined.

\begin{tabular}{|c|c|c|c|c|c|c|c|c|}
\hline & & $\begin{array}{c}2001 \\
(n 619) \\
(\text { wt } n 5015)\end{array}$ & $\begin{array}{c}2002 \\
(n 585) \\
(\text { wt } n \text { 4967) }\end{array}$ & $\begin{array}{c}2003 \\
(n 546) \\
(\text { wt } n \text { 4952) }\end{array}$ & $\begin{array}{c}2004 \\
(n 590) \\
(\text { wt } n \text { 4948) }\end{array}$ & $\begin{array}{c}2005 \\
(n 566) \\
(\text { wt } n \text { 4939) }\end{array}$ & $\begin{array}{c}2006^{1} \\
(n 577) \\
\text { (wt } n \text { 4906) }\end{array}$ & $\begin{array}{c}P \text {-value for Linear } \\
\text { Association }\end{array}$ \\
\hline $\begin{array}{l}\text { Fruit and Vegetables } \\
\text { (g per person per } d)\end{array}$ & $\begin{array}{l}\text { Mean } \\
95 \% \text { CI }\end{array}$ & $\begin{array}{c}239 \\
222,257\end{array}$ & $\begin{array}{c}243 \\
224,261\end{array}$ & $\begin{array}{c}228 \\
209,246\end{array}$ & $\begin{array}{c}246 \\
225,267\end{array}$ & $\begin{array}{c}262 \\
244,281\end{array}$ & $\begin{array}{c}256 \\
238,274\end{array}$ & 0.023 \\
\hline $\begin{array}{l}\text { Fruit }^{2} \\
\text { (g per person per } d)\end{array}$ & $\begin{array}{l}\text { Mean } \\
95 \% \mathrm{CI}\end{array}$ & $\begin{array}{c}123 \\
111,136\end{array}$ & $\begin{array}{c}127 \\
113,141\end{array}$ & $\begin{array}{c}119 \\
106,132\end{array}$ & $\begin{array}{c}130 \\
117,143\end{array}$ & $\begin{array}{c}142 \\
129,155\end{array}$ & $\begin{array}{c}138 \\
127,150\end{array}$ & 0.009 \\
\hline $\begin{array}{l}\text { Vegetables }{ }^{3} \\
\text { (g per person per } d)\end{array}$ & $\begin{array}{l}\text { Mean } \\
95 \% \text { CI }\end{array}$ & $\begin{array}{c}116 \\
108,124\end{array}$ & $\begin{array}{c}115 \\
108,123\end{array}$ & $\begin{array}{c}109 \\
100,117\end{array}$ & $\begin{array}{c}116 \\
107,126\end{array}$ & $\begin{array}{c}120 \\
113,128\end{array}$ & $\begin{array}{c}118 \\
107,128\end{array}$ & 0.386 \\
\hline
\end{tabular}

$n$ refers to the number of households and weighted (wt) $n$ refers to the weighted number of people in the sample.

${ }^{1}$ From 2006, the EFS moved from a financial year to a calendar year basis. As a consequence of this, the January to March 2006 data are duplicated in the 2005 and the 2006 results. ${ }^{2}$ Includes fruit and vegetable juice. ${ }^{3}$ Includes baked beans.

\begin{tabular}{|c|c|c|c|c|c|c|c|}
\hline & & \multicolumn{5}{|c|}{ Scottish Index of Multiple Deprivation Quintile $^{1}$} & \multirow[b]{2}{*}{$\begin{array}{l}P \text {-value for linear } \\
\text { association }\end{array}$} \\
\hline & & $\begin{array}{c}1 \\
\text { Most deprived } \\
(n \text { 336) } \\
\text { (wt } n \text { 2740) }\end{array}$ & $\begin{array}{c}2 \\
(n 346) \\
(\text { wt } n 2776)\end{array}$ & $\begin{array}{c}3 \\
\left(\begin{array}{c}n \\
345)\end{array}\right. \\
(\text { wt } n \text { 2855) }\end{array}$ & $\begin{array}{c}4 \\
(n 310) \\
(\text { wt } n 2668)\end{array}$ & $\begin{array}{c}5 \\
\text { Least deprived } \\
(n \text { 394) } \\
(\text { wt } n \text { 3738) }\end{array}$ & \\
\hline $\begin{array}{l}\text { Fruit and vegetables } \\
\text { (g per person per } d)\end{array}$ & $\begin{array}{l}\text { Mean } \\
95 \% \mathrm{CI}\end{array}$ & $\begin{array}{c}196 \\
175,217\end{array}$ & $\begin{array}{c}228 \\
207,249\end{array}$ & $\begin{array}{c}244 \\
221,267\end{array}$ & $\begin{array}{c}286 \\
263,309\end{array}$ & $\begin{array}{c}304 \\
285,323\end{array}$ & $<0.001$ \\
\hline $\begin{array}{l}\text { Fruit }^{2} \\
\text { (g per person per d) }\end{array}$ & $\begin{array}{l}\text { Mean } \\
95 \% \mathrm{CI}\end{array}$ & $\begin{array}{c}95.9 \\
81.7,110\end{array}$ & $\begin{array}{c}120 \\
106,133\end{array}$ & $\begin{array}{c}129 \\
117,142\end{array}$ & $\begin{array}{c}160 \\
145,176\end{array}$ & $\begin{array}{c}168 \\
154,183\end{array}$ & $<0.001$ \\
\hline $\begin{array}{l}\text { Vegetables } \\
\text { (g per person per } d)\end{array}$ & $\begin{array}{l}\text { Mean } \\
95 \% \text { CI }\end{array}$ & $\begin{array}{c}99.9 \\
90.4,109\end{array}$ & $\begin{array}{c}108 \\
98.1,118.5\end{array}$ & $\begin{array}{c}115 \\
103,127\end{array}$ & $\begin{array}{c}125 \\
113,137.5\end{array}$ & $\begin{array}{c}136 \\
123,149\end{array}$ & $<0.001$ \\
\hline
\end{tabular}

$n$ refers to the number of households and weighted (wt) $n$ refers to the weighted number of people in the sample.

${ }^{1}$ Combined data for years 2004 to $2006 .{ }^{2}$ Includes fruit and vegetable juice. ${ }^{3}$ Includes baked beans.

A small (17 g) but statistically significant increase was found in the mean daily consumption of fruit and vegetables for the period 2001 to 2006. This is due to an increase in fruit consumption with no significant change to vegetable consumption over the period. Inclusion of fruit juice increases the consumption figures by the equivalent of half a portion per day; however, the proportion of fruit to fruit juice remained similar over the time period. A clear gradient was found in fruit and vegetable consumption by SIMD quintile, with the most deprived quintile consuming one-third less than the least deprived quintile.

Mean fruit and vegetable consumption remains almost $150 \mathrm{~g}$ ( 2 portions) below the population target of $>400 \mathrm{~g} / \mathrm{d}$. The linear modelling showed that if the current rate of increase was to continue, it would take 37 years to reach the $>400 \mathrm{~g} / \mathrm{d}$ target.

Funding provided by Food Standards Agency Scotland is gratefully acknowledged (Project no. S14035). Data provided by the Department for the Environment, Food and Rural Affairs, Scottish Neighborhood Statistics, the Office of National Statistics and the UK Data Archive.

1. Department of Environment, Food and Rural Affairs/Office for National Statistics (2008) Family Food. A Report on the 2007 Expenditure and Food Survey. London: The Stationery Office.

2. Waste and Resource Action Programme (2007) The Food We Waste. http://www.wrap.org.uk/retail/case_studies_research/report_the_food_we.html 